\title{
KARAKTERISTIK COOKIES DARI TEPUNG TERIGU DAN TEPUNG BIJI NANGKA DIMODIFIKASI SECARA ENZIMATIS
}

\author{
Siska Cicilia ${ }^{1}$, Eko Basuki ${ }^{1}$, Ahmad Alamsyah ${ }^{1}$, I Wayan Sweca Yasa ${ }^{1}$, Lingga Gita \\ Dwikasari ${ }^{1}$, Rafika Suari ${ }^{1}$ \\ ${ }^{1}$ Program Studi Ilmu dan Teknologi Pangan, Fakultas Teknologi Pangan dan Agroindustri, \\ Universitas Mataram, Mataram \\ *email korespondensi: siskacicilia@unram.ac.id
}

\begin{abstract}
ABSTRAK
Penelitian ini bertujuan untuk mengetahui karakteristik cookies berbahan dasar gandum dengan penambahan tepung biji nangka termodifikasi secara enzimatis. Penelitian ini menggunakan metode eksperimen dengan Rancangan Acak Lengkap (RAL) satu faktor yang terdiri dari 6 taraf perbandingan penggunaan tepung terigu : tepung biji nangka termodifikasi yaitu $\mathrm{P} 1=100 \%$ : 0\%, P2=85\% : 15\% , P3=70\% : 30\%, P4=55\% : 45\%, P5=40\% : 60\% dan $\mathrm{P} 6=25 \%: 75 \%$ dengan 3 kali pengulangan. Parameter yang diamati meliputi parameter kimia yaitu kadar air, abu, protein, kadar lemak dan organoleptik (warna, rasa, dan tekstur). Data yang diamati dianalisis ragamnya (Analysis of Variance) dengan taraf signifikansi 5\%. Jika terdapat perbedaan yang signifikan maka dilakukan uji lanjut Polynomial Orthogonal (MOP) untuk parameter kimia dan uji Duncan untuk organoleptik. Hasil penelitian menunjukkan bahwa penambahan tepung biji nangka termodifikasi dengan konsentrasi yang berbeda memberikan pengaruh yang berbeda nyata pada semua parameter kimia dan organoleptik. Semakin tinggi penambahan tepung biji nangka termodifikasi menyebabkan peningkatan kadar air, kadar abu, kadar protein, kadar lemak, warna lebih gelap, tekstur lebih padat dan rasa pahit. Perlakuan dengan perbandingan tepung 55\% : 45\% tepung biji nangka termodifikasi merupakan perlakuan terbaik dengan kadar air 6,94\%; 1,13\% kadar abu; Kandungan protein 7,95\% dan kandungan lemak 17,63\%.
\end{abstract}

Kata Kunci: cookies ; modifikasi enzimatis; tepung biji nangka

\section{ABSTRACT}

This study aims to determine the characteristics of cookies made from wheat with the addition of enzymatically modified jackfruit seed flour. This study used an experimental method with a one-factor Completely Randomized Design (CRD) consisting of 6 levels of the ratio of the use of wheat flour: modified jackfruit seed flour, namely P1=100\% : 0\%, P2=85\%: $15 \%, \mathrm{P} 3=70 \%: 30 \%$, $\mathrm{P} 4=55 \%: 45 \%, \mathrm{P} 5=40 \%: 60 \%$ and $\mathrm{P} 6=25 \%: 75 \%$ with 3 repetitions. Parameters observed included chemical parameters, namely moisture, ash, protein, fat content and organoleptic (color, taste, and texture). The observed data were analyzed for variance (Analysis of Variance) with a significance level of $5 \%$. If there is a significant difference, the Polynomial Orthogonal (MOP) further test for

$1 \quad$ Karakteristik Cookies dari Tepung Terigu dan Tepung Biji Nangka Dimodifikasi Secara Enzimatis/Siska Cicilia $^{1 *}$, Eko Basuki ${ }^{*}$, Ahmad Alamsyah $^{1 *}$, I Wayan Sweca Yasa ${ }^{1 *}$, Lingga Gita Dwikasari $^{1 *}$, Rafika Suari $^{2}$

Journal of Agritechnology and Food Processing

Volume 1, No. 1, 2021

Jl. K. H. Ahmad Dahlan No. 1, Pagesangan-Mataram, Indonesia 
chemical parameters and Duncan's test for organoleptic is carried out. The results showed that the addition of modified jackfruit seed flour with different concentrations gave significantly different effects on all chemical and organoleptic parameters. The higher the addition of modified jackfruit seed flour causes an increase in water content, ash content, protein content, fat content, darker color, denser texture and bitter taste. Treatment with a ratio of 55\% flour: $45 \%$ modified jackfruit seed flour was the best treatment with $6.94 \%$ moisture content; $1.13 \%$ ash content; $7.95 \%$ protein content and $17.63 \%$ fat content.

\section{Keywords: cookies ; enzymatically modified; jackfruit seed flour}

\section{PENDAHULUAN}

Nangka merupakan salah satu buah yang banyak tumbuh di daerah beriklim tropis. Penampakan luar buah nangka berupa duri yang lunak tetapi tidak tidak tajam dan pendek. Aroma buah nangka sangat khas (Adelina \& Tiwow, 2020). Di dalam buah nangka terdapat daging buah, dami (jerami), dan biji nangka. Daging buah dan dami nangka banyak dimanfaatkan dalam pembuatan aneka makanan sedangkan biji nangka menjadi limbah. Pemanfaatan biji nangka sangat terbatas yaitu berupa sayur atau kolak.

Menurut (Andyarini, 2017), dalam 100g biji nangka terdapat energi $165 \mathrm{kkal} /$ protein 4,2 g; lemak 0,1 g; karbohidrat 36,7 g; kalsium 33 mg; besi 200 mg; fosfor 1,0 mg; vit B1 0,20 $\mathrm{mg}$; vit C 10,0 mg; air 57\%. Selain itu, biji nangka juga dikenal dengan fitonutriennya seperti lignin, isoflavon dan saponin yang merupakan senyawa antioksidan yang dapat membantu melawan efek radikal bebas yang dapat merusak sel, fitokimia dalam biji nangka juga dapat mencegah pertumbuhan sel kanker dan setiap $100 \mathrm{~g}$ biji nangka tinggi akan kalsium $33 \mathrm{mg}$ dan fosfor $200 \mathrm{mg}$. Peranan kalsium dan fosfor bagi tubuh manusia diantaranya adalah untuk memperkuat tulang dan gigi (Daeng, 2019). Untuk meningkatkan pemanfaatan biji nangka, maka biji nangka dapat diolah menjadi tepung. Proses pembuatan tepung biji nangka melalui pengeringan pada suhu $60^{\circ} \mathrm{C}$ selama 2 jam menggunakan cabinet dryer.

Tepung biji nangka sangat berpotensi dikembangkan sebagai bahan pensubstitusi tepung terigu dalam pembuatan produk bakery karena dapat berfungsi sebagai penstabil dan memiliki daya ikat air yang tinggi (Santoso et al., 2014). Pada saat gelatinisasi, pati mengikat air dan air tersebut akan menguap saat pemanasan (pengovenan). Hal inilah yang menyebabkan tekstur cookies menjadi renyah (Adikhairani, 2012).

Kandungan protein tepung biji nangka diketahui sebesar 4,2\%. Untuk meningkatkan kandungan protein tersebut maka dilakukan modifikasi secara enzimatis menggunakan $\alpha$ amilase dari kecambah kacang hijau. Beberapa penelitian menunjukkan modifikasi dengan

\footnotetext{
2 Karakteristik Cookies dari Tepung Terigu dan Tepung Biji Nangka Dimodifikasi Secara Enzimatis/Siska Cicilia $^{1 *}$, Eko Basuki $^{{ }^{*}}$, Ahmad Alamsyah $^{{ }^{*}}$, I Wayan Sweca Yasa $^{1 *}$, Lingga Gita Dwikasari $^{1 *}$, Rafika Suari $^{2}$

Journal of Agritechnology and Food Processing

Volume 1, No. 1, 2021

Jl. K. H. Ahmad Dahlan No. 1, Pagesangan-Mataram, Indonesia
} 
$\alpha$-amilase dari kecambah kacang hijau secara signifikan meningkatkan kandungan protein tepung. Penambahan enzim $\alpha$-amilase pada tepung biji nangka sebanyak $35 \%$ menghasilkan kadar protein tertinggi yaitu 17,59\% (Ma'rufah et al., 2016), penambahan $20 \% \alpha$-amilase pada tepung jagung meningkatkan kandungan protein menjadi 14,05\% (Suarni et al., 2010), ekstrak kecambah kacang hijau 40\% meningkatkan protein tepung talas (Hariyadi et al., 2020).

Pembuatan cookies dari tepung biji nangka dimodifikasi belum pernah diteliti. Akan tetapi, substitusi tepung biji nangka pada pembuatan cookies menunjukkan peningkatan kadar lemak dan kadar serat seiring dengan peningkatan penggunaan tepung biji nangka (Islam et al., 2015). Penambahan 30\% tepung biji nangka menghasilkan cookies yang paling disukai panelis (Kisnawaty \& Kurnia, 2017).

\section{METODE PENELITIAN}

\section{A. Bahan dan Alat Penelitian}

Bahan yang digunakan adalah biji nangka kunir didapatkan di Suranadi, kacang hijau varietas Sempoeng, tepung terigu rendah protein, margarin, susu skim, ragi,air, telur, gula, garam, baking powder serta bahan untuk analisis anatara lain $\mathrm{Na}_{2} \mathrm{SO}_{4}$ pekat, $\mathrm{CuSO}_{4}$, akuades, $\mathrm{Zn}, \mathrm{NaOH}$, dan $\mathrm{HCl}$.

Alat-alat yang digunakan adalah set peralatan pembuatan cookies serta alat untuk analisis seperti oven, desikator, cabinet dryer, label bulb, tanur, labu kjehdal, kompor pemanas, buret, cawan porselin, tang penjepit, mortal dan glassware.

\section{B. Rancangan Percobaan}

Metode yang digunakan dalam penelitian ini adalah metode eksperimental yang dilaksanakan di laboratorium dengan rancangan percobaan Rancangan Acak Lengkap (RAL) dengan satu faktor, yaitu rasio tepung terigu dan tepung biji nangka dimodifikasi (P). Formulasi bahan baku pembuatan cookies dapat dilihat pada Tabel 1.

$3 \quad$ Karakteristik Cookies dari Tepung Terigu dan Tepung Biji Nangka Dimodifikasi Secara Enzimatis/Siska Cicilia $^{1 *}$, Eko Basuki $^{1 *}$, Ahmad Alamsyah $^{1 *}$, I Wayan Sweca Yasa $^{1 *}$, Lingga Gita Dwikasari $^{*}$, Rafika Suari $^{2}$

Journal of Agritechnology and Food Processing

Volume 1, No. 1, 2021

Jl. K. H. Ahmad Dahlan No. 1, Pagesangan-Mataram, Indonesia 
Tabel 1. Formulasi Bahan Pembuatan Cookies

\begin{tabular}{lllllll}
\hline \multirow{2}{*}{ Bahan } & \multicolumn{5}{l}{ Perlakuan (P, Tepung Terigu:Tepung Biji Nangka Dimodifikasi) } \\
\cline { 2 - 7 } & P1 & P2 & P3 & P4 & P5 & P6 \\
& $(100: 0)$ & $(85: 15)$ & $(70: 30)$ & $(55: 45)$ & $(40: 60)$ & $(25: 75)$ \\
\hline Tepung terigu (g) & 100 & 85 & 70 & 55 & 40 & 25 \\
\hline $\begin{array}{l}\text { Tepung biji nangka } \\
\text { dimodifikasi (g) }\end{array}$ & 0 & 15 & 30 & 45 & 60 & 75 \\
\hline Margarin (g) & 50 & 50 & 50 & 50 & 50 & 50 \\
\hline Gula Halus (g) & 75 & 75 & 75 & 75 & 75 & 75 \\
\hline Garam (g) & 2 & 2 & 2 & 2 & 2 & 2 \\
\hline Baking Powder (g) & 2 & 2 & 2 & 2 & 2 & 2 \\
\hline Kuning Telur (g) & 40 & 40 & 40 & 40 & 40 & 40 \\
\hline Susuk Bubuk (g) & 15 & 15 & 15 & 15 & 15 & 15 \\
\hline Total Bahan (g) & 284 & 284 & 284 & 284 & 284 & 284 \\
\hline
\end{tabular}

\section{Tahapan Penelitian}

\section{Pembuatan Tepung Biji Nangka Biji nangka (Ma'rufah, 2016)}

Biji nangka yang digunakan disortasi dan dicuci. Biji nangka kemudian direbus pada suhu $70^{\circ} \mathrm{C}$ selama 30 menit untuk melunakkan biji dan mengurangi bau.Tahap selanjutnya adalah pengirisan menggunakan slicer dengan ketebalan $1 \mathrm{~mm}$ selanjutnya dikeringkan menggunakan cabinet dryer pada suhu $60^{\circ} \mathrm{C}$ selama 2 jam. Irisan biji nangka kering dihaluskan menggunakan blender dan diayak dengan ayak 80 mesh.

\section{Pembuatan Tepung Kecambah Kacang Hijau (Modifikasi Ma'rufah, 2016)}

Kacang hijau yang sudah disortasi dan dicuci kemudian direndam selama 30 menit pada suhu ruang. Tahap selanjutnya adalah perkecambahan yang dilakukan selama 36 jam pada suhu ruang, dilanjutkan dengan pengukusan selama 15 menit pada suhu $90^{\circ} \mathrm{C}$. Setelah itu dilakukan pengeringan menggunakan cabinet dryer pada suhu $50^{\circ} \mathrm{C}$ selama 7 jam, dihaluskan, dan diayak.

\section{Pembuatan Tepung Biji Nangka Dimodifikasi (Suarni dan Patong, 2007)}

Tepung biji nangka (65\%) dicampurkan dengan tepung kecambah kacang hijau (35\%) dilanjutkan dengan hidrolisis enzimatis pada suhu $85^{\circ} \mathrm{C}$ selama 40 menit. Selanjutnya, dikeringkan menggunakan cabinet dryer dengan suhu $50^{\circ} \mathrm{C}$ selama 2 jam kemudian dihaluskan dan diayak (80 mesh).

4 Karakteristik Cookies dari Tepung Terigu dan Tepung Biji Nangka Dimodifikasi Secara Enzimatis/Siska Cicilia $^{1 *}$, Eko Basuki $^{{ }^{*}}$, Ahmad Alamsyah $^{{ }^{*}}$, I Wayan Sweca Yasa $^{1 *}$, Lingga Gita Dwikasari $^{1 *}$, Rafika Suari $^{2}$

Journal of Agritechnology and Food Processing

Volume 1, No. 1, 2021

Jl. K. H. Ahmad Dahlan No. 1, Pagesangan-Mataram, Indonesia 


\section{Pembuatan Cookies}

Bahan berupa margarin, gula, garam, baking powder menggunakan mixer selama 5 menit hingga diperoleh adonan yang licin dan putih kemudian ditambahkan kuning telur dan dimixer selama 2 menit. Bahan yang terakhir ditambahkan adalah susu dan campuran tepung sesuai perlakuan. Bahan yang sudah dicampur membentuk adonan, digiling, dicetak, dioleskan kuning telur di permukaan adonan, dan dipanggang selama 20 menit pada suhu $150^{\circ} \mathrm{C}$ (Pratiwi, 2008).

\section{Analisis Cookies}

Parameter yang akan diamati meliputi analisis kadar air (metode termogravimetri), kadar abu (metode pengabuan kering),kadar protein (metode kjeldahl), kadar lemak (metode soxhlet), dan organoleptik (tekstur, rasa, dan warna) secara skoring. Data hasil pengamatan dianalisis menggunakan perangkat lunak Co-Stat dengan analisis sidik ragam (ANOVA) pada taraf nyata 5\%. Apabila terdapat bedanyata antara perlakuan maka dilakukan uji lanjut dengan metode orthogonal polynomial (MOP) pada taraf 5\% untuk kadar air, kadar abu, kadar protein, kadar lemak. Uji Duncan's Multiple Range Test (DMRT) digunakan untuk parameter organoleptik berupa tekstur, warna, dan rasa.

\section{HASIL DAN PEMBAHASAN}

\section{A. Kadar Air}

Kadar air merupakan persentase sejumlah kandungan air yang terkandung di dalam suatu bahan. Kadar air juga salah satu karakteristik yang sangat penting pada bahan pangan, karena air dapat mempengaruhi penampakan, tekstur, dan citarasa pada bahan pangan. Kadar air dalam bahan pangan ikut menentukan kesegaran dan daya awet bahan pangan tersebut (Winarno, 2002). Adapun pengaruhpenambahan tepung biji nangka dimodifikasi terhadap kadar air cookies dapat dilihat pada Gambar 1.

$5 \quad$ Karakteristik Cookies dari Tepung Terigu dan Tepung Biji Nangka Dimodifikasi Secara Enzimatis/Siska Cicilia $^{1 *}$, Eko Basuki ${ }^{1 *}$, Ahmad Alamsyah $^{1 *}$, I Wayan Sweca Yasa ${ }^{1 *}$, Lingga Gita Dwikasari $^{1 *}$, Rafika Suari $^{2}$ Journal of Agritechnology and Food Processing Volume 1, No. 1, 2021

Jl. K. H. Ahmad Dahlan No. 1, Pagesangan-Mataram, Indonesia 


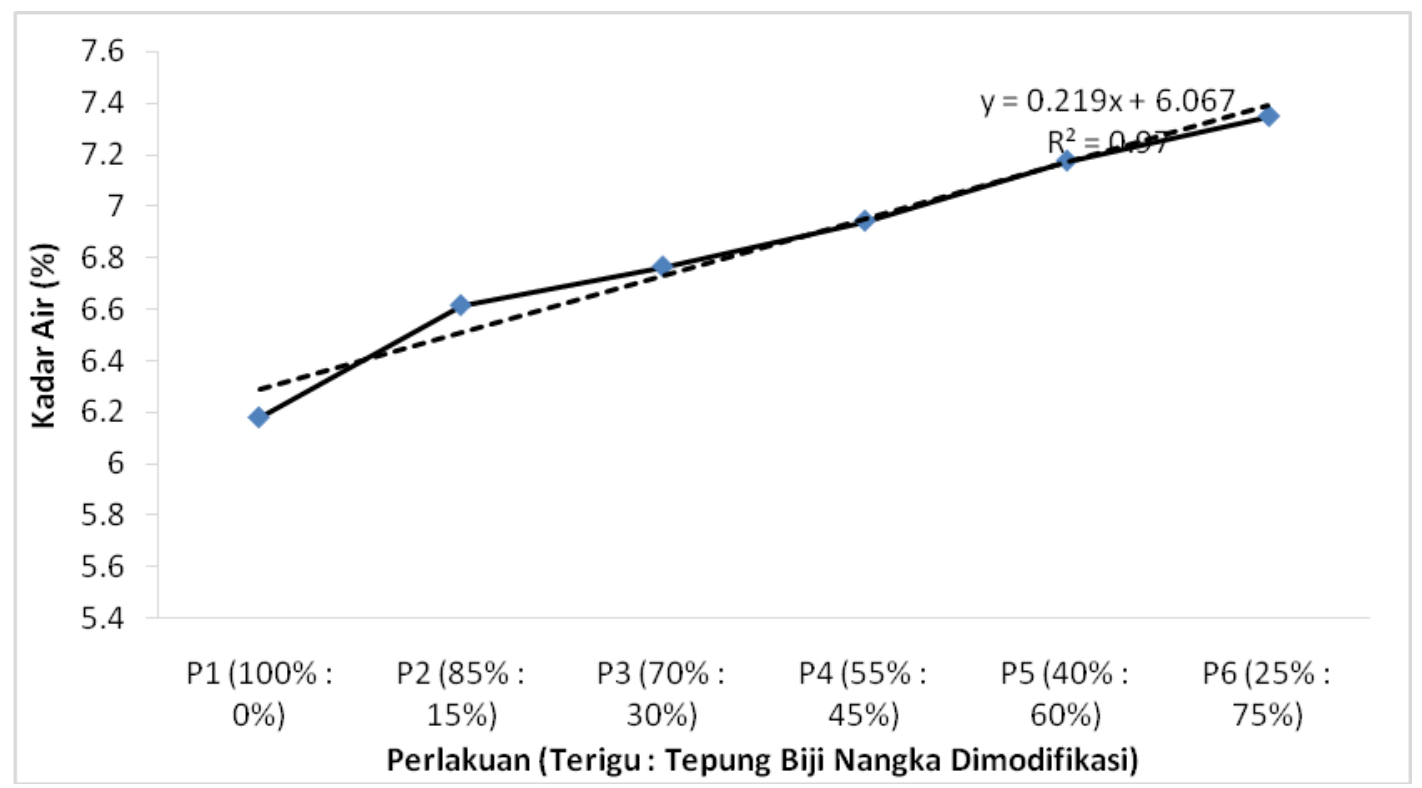

\section{Gambar 1. Grafik Pengaruh Penambahan Tepung Biji Nangka Dimodifikasi terhadap} Kadar Air Cookies

Gambar 1 menunjukkan bahwa semakin tinggi penambahan tepung biji nangka dimodifikasi maka kadar air semakin meningkat dengan pola regresi yang terbentuk yaitu linier dengan persamaan $y=0,2199 x+6,068$ dan dengan koefisien determinasi (KD) $R^{2}=$ 0,97 . Nilai 0,2199 merupakan nilai yang menentukan arah regresi linier, karena nilainya positif, hal ini menunjukkan hubungan yang positif, artinya semakin meningkatnya presentase penambahan tepung biji nangka dimodifikasi pada cookies, menyebabkan peningkatan kadar air. Hal ini berarti semakin tinggi konsentrasi tepung biji nangka dimodifikasi yang ditambahkan maka akan menyebabkan peningkatan kadar air cookies sebesar 0,2199. Hal ini karena kadar air dari tepung biji nangka dimodifikasi yang tinggi. Nilai 6,068 merupakan konstanta atau disebut incept dimana pada titik x=0, nilai kadar air sebesar 6,068. Nilai koefisian determinasi (KD) sebesar 0,97 dikonversi ke \% sehingga menjadi $97 \%$, artinya yaitu peningkatan kadar air cookies dipengaruhi sebesar $97 \%$ oleh tepung biji nangka dimodifikasi dan sisanya sebesar $3 \%$ dipengaruhi oleh faktor lain.

Peningkatan kadar air cookies dengan penambahan tepung biji nangka dimodifikasi disebabkan oleh kandungan tepung biji nangka yang dimodifiakasi memiliki kadar air lebih tinggi dibandingkan tepung terigu. Berdasarkan hasil analisis kadar air tepung biji nangka dimodifikasi yang didapatkan yaitu 10,46\%, sedangkan kadar air pada tepung terigu yaitu sebesar 7,41\%. Tingginya kadar air pada tepung biji nangka dimodifikasi karena banyaknya enzim dari kecambah kacang hijau yang ditambahkan untuk memecah pati. Semakin banyak enzim, maka semakin banyak pula rantai amilosa yang pecah. Pati dengan amilosa

6 Karakteristik Cookies dari Tepung Terigu dan Tepung Biji Nangka Dimodifikasi Secara Enzimatis/Siska Cicilia $^{1^{*}}$, Eko Basuki $^{1^{*}}$, Ahmad Alamsyah $^{1 *}$, I Wayan Sweca Yasa ${ }^{1 *}$, Lingga Gita Dwikasari $^{{ }^{*}}$, Rafika Suari $^{2}$

Journal of Agritechnology and Food Processing

Volume 1, No. 1, 2021

Jl. K. H. Ahmad Dahlan No. 1, Pagesangan-Mataram, Indonesia 
yang rendah kemampuan untuk mengikat air semakin tinggi, sebaliknya pati dengan kadar amilosa tinggi cenderung mengalami interaksi antar rantai molekul polimer atau mudah mengalami ikatan silang sehingga menghalangi masuknya molekul air (Narsito, 2007).

Hasil penelitian cookies dari perbandingan tepung biji nangka kadar air yang dihasilkan adalah 6,18\%-7,35\%. Jika mengacu pada Standar Nasional Indonesia cookies (01-2973-1992), syarat mutu cookies untuk kadar air yaitu maksimal 5\%, sehingga untuk kadar air cookies belum memenuhi standar mutu SNI cookies.

\section{B. Kadar Abu}

Kadar abu adalah parameter untuk menunjukkan nilai kandungan bahan anorganik (mineral) yang ada didalam suatu bahan pangan atau produk pangan. Kandungan abu dan komposisinya tergantung pada jenis bahan dan cara pengabuannya (Sudarmadji, 1997). Pengaruh penambahan tepung biji nangka dimodifikasi terhadap kadar abu cookies dapat dilihat pada Gambar 2.

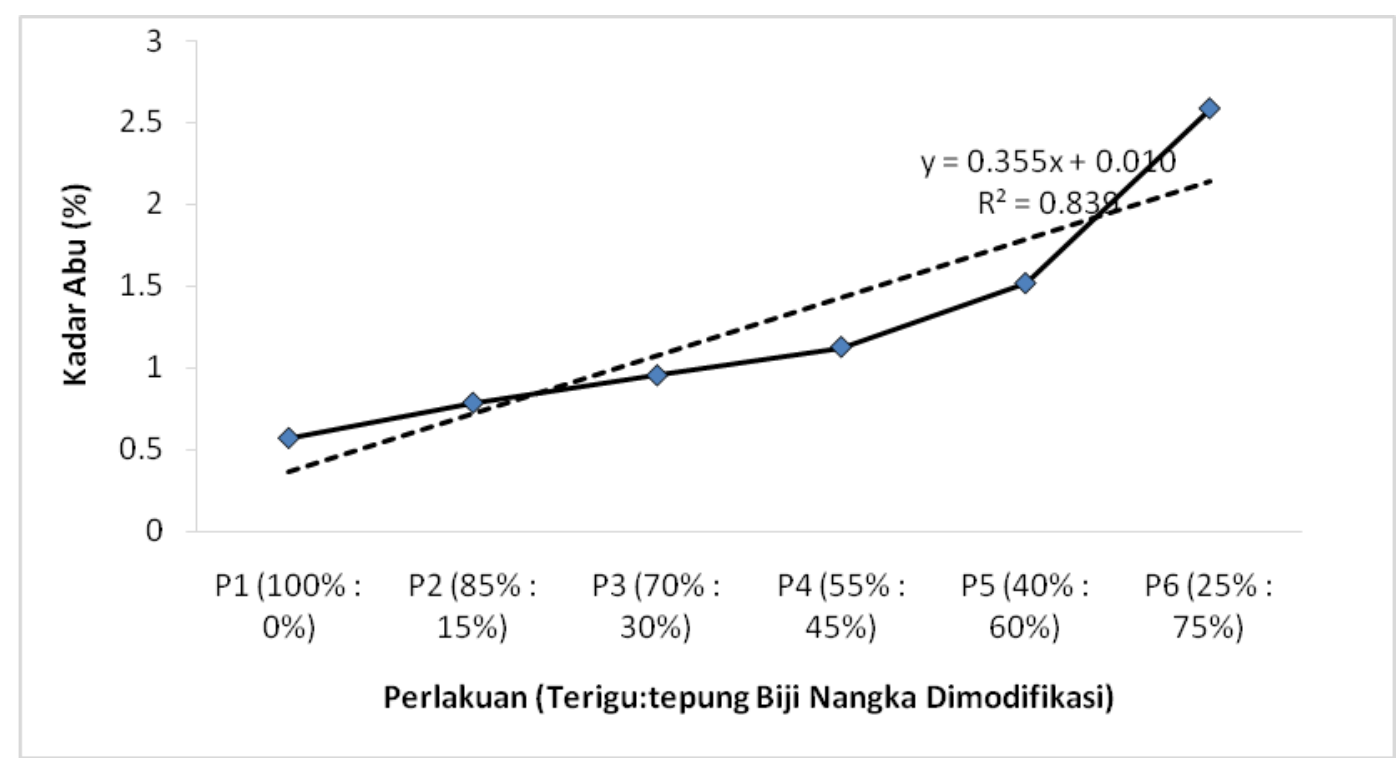

\section{Gambar 2. Grafik Pengaruh Penambahan Tepung Biji Nangka Dimodifikasi terhadap Kadar Abu Cookies}

Gambar 2 menunjukkan bahwa semakin tinggi penambahan tepung biji nangka dimodifikasi pada pembuatan cookies maka kadar abu cookies tersebut semakin meningkat dengan pola regresi linear dengan persamaan regresi $y=0,3556 x+0,01$ dan dengan koefisien determinasi $(R 2)=0,8394$. Nilai 0,3556x menentukan arah regresi linear. Nilai positif pada angka ini menunjukkan hubungan yang positif terhadap penambahan

7 Karakteristik Cookies dari Tepung Terigu dan Tepung Biji Nangka Dimodifikasi Secara Enzimatis/Siska
Cicilia $^{1 *}$, Eko Basuki ${ }^{*}$, Ahmad Alamsyah ${ }^{1 *}$, I Wayan Sweca Yasa ${ }^{*}$, Lingga Gita Dwikasari $^{{ }^{*}}$, Rafika Suari $^{2}$
Journal of Agritechnology and Food Processing
Volume 1, No. 1, 2021
Jl. K. H. Ahmad Dahlan No. 1, Pagesangan-Mataram, Indonesia 
tepung biji nangka dimodifikasi. Semakin tinggi penambahan tepung biji nangka dimodifikasi maka akan terjadi peningkatan pada kadar abu pada cookies sebesar 0,3556. Nilai 0,01 merupakan konstanta atau disebut intercept dimana pada titik $\mathrm{x}=0$, kadar abu sebesar 0,01. Nilai koefisien determinasi (KD) sebesar 0,8394 dikonversi ke \% sehingga menjadi 83,94\%, artinya yaitu peningkatan kadar abu cookies dipengaruhi sebesar $83,94 \%$ oleh penambahan tepung tepung biji nangka dimodifikasi dan sisanya sebesar $16,06 \%$ dipengaruhi oleh faktor lain.

Semakin tinggi konsentrasi tepung biji nangka dimodifikasi yang disubstitusikan akan menghasilkan kadar abu yang semakin tinggi disebabkan karena kadar abu dari bahan dasar. Berdasarkan hasil penelitian kadar abu tepung biji nangka dimodifikasi sebesar $3,77 \%$ dan tepung terigu yaitu $0,63 \%$. Besarnya nilai kadar abu cookies dipengaruhi oleh besarnya jumlah mineral yang terkandung dalam suatu bahan. Kadar abu dalam suatu bahan pangan menunjukkan nilai kandungan bahan anorganik (mineral) yang ada di dalam bahan pangan tersebut. Semakin tinggi nilai kadar abu maka semakin banyak kandungan bahan anorganik yang ada di dalamnya. Komponen bahan anorganik di dalam suatu bahan sangat bervariasi baik jenis maupun jumlahnya yakni diantaranya natrium, kalsium, kalium, fosfor, besi, magnesium dan lain-lain. Tepung biji nangka tanpa dimodifikasi dan tepung biji nangka dimodifikasi tetap mengandung mineral seperti kalsium dan fosfor, selama perkecambahan tidak ditambahkan mineral. Selama proses inkubasi juga tidak membutuhkan senyawa anorganik, sehingga kandungan mineral tepung biji nangka sebelum dan sesudah dimodifikasi tidak banyak berubah, sedangkan pada tepung terigu banyak mengandung mineral seperti fosfor, magnesium.

Menurut Sediaoetama (2010) kadar abu menggambarkan banyaknya mineral yang tidak terbakar menjadi zat yang dapat menguap. Kadar abu yaitu sisa yang tertinggal bila suatu sampel bahan makanan dibakar sempurna. Kadar abu cookies maksimal yang telah ditetapkan dalam SNI 01-2973-1992 adalah maksimal 1,5\%. Hasil penelitian didapatkan bahwa kisaran kadar abu cookies dengan perbandingan konsentrasi tepung biji nangka dimodifikasi dan tepung terigu yaitu $0,57-2,58 \%$. Hal ini menunjukan bahwa kadar abu produk cookies sudah memenuhi standar mutu yang ditetapkan oleh Badan Standar Nasional.

\section{Kadar Protein}

Protein merupakan salah satu senyawa yang penting bagi tubuh, hal ini dikarenakan protein berfungsi sebagai sumber energi selain karbohidrat dan lemak. Protein terdiri dari unsur $\mathrm{C}, \mathrm{H}, \mathrm{O}$ dan $\mathrm{N}$ yang tidak dimiliki oleh lemak atau karbohidrat.

8 Karakteristik Cookies dari Tepung Terigu dan Tepung Biji Nangka Dimodifikasi Secara Enzimatis/Siska
Cicilia $^{1 *}$, Eko Basuki ${ }^{1 *}$, Ahmad Alamsyah ${ }^{1 *}$, I Wayan Sweca Yasa ${ }^{1 *}$, Lingga Gita Dwikasari $^{*}$, Rafika Suari $^{2}$
Journal of Agritechnology and Food Processing
Volume 1, No. 1, 2021
Jl. K. H. Ahmad Dahlan No. 1, Pagesangan-Mataram, Indonesia 
Pengaruh penambahan tepung biji nangka dimodifikasi terhadap kadar proteincookies dapat dilihat pada Gambar 3.

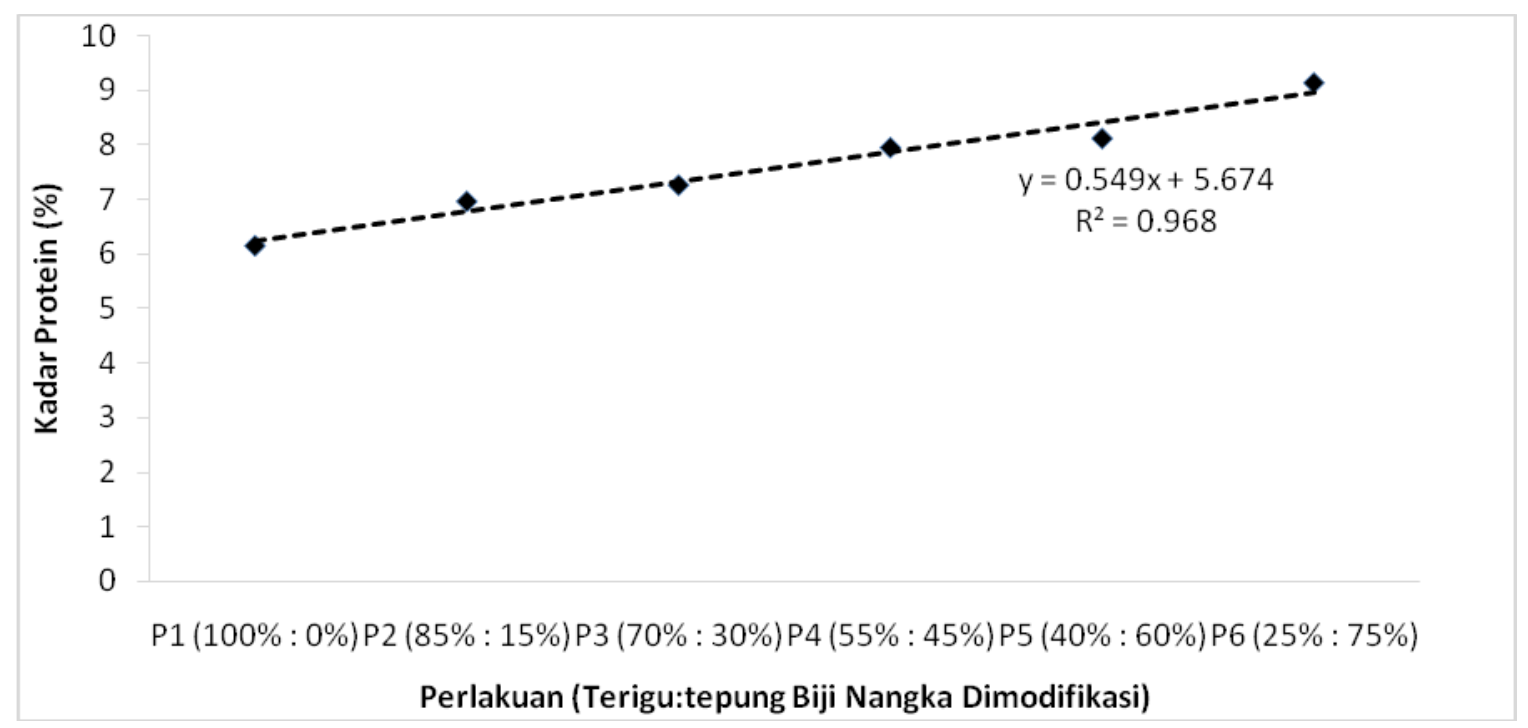

\section{Gambar 3. Grafik Pengaruh Penambahan Tepung Biji Nangka Dimodifikasi terhadap Kadar Protein Cookies}

Gambar 3 menunjukkan bahwa semakin tinggi penambahan tepung biji nangka dimodifikasi pada pembuatan cookies maka kadar protein cookies tersebut semakin meningkat dengan pola regresi linear dengan persamaan regresi $y=0,5491 x+5,6753$ dan dengan koefisien determinasi $(R 2)=0,968$. Nilai $0,5491 x$ menentukan arah regresi linear. Nilai positif pada angka ini menunjukkan hubungan yang positif terhadap penambahan tepung biji nangka dimodifikasi. Semakin tinggi penambahan tepung biji nangka dimodifikasi maka akan terjadi peningkatan pada kadar protein pada cookies sebesar 0,5491 . Nilai 5,6753merupakan konstanta atau disebut intercept dimana pada titik $x=0$, kadar abu sebesar 5,6753. Nilai koefisien determinasi (KD) sebesar 0,968 dikonversi ke \% sehingga menjadi $96,8 \%$, artinya yaitu peningkatan kadar protein cookies dipengaruhi sebesar $96,8 \%$ oleh penambahan tepung tepung biji nangka dimodifikasi dan sisanya sebesar 3,2\% dipengaruhi oleh faktor lain.

Peningkatan kandungan protein pada cookies ini dikarenakan kandungan protein tepung biji nangka dimodifikasi lebih tinggi yaitu 16,1\% dan tepung terigu hanya memiliki kandungan protein sebesar $6,8 \%$. Adapun, kandungan protein pada tepung biji nangka tanpa dimodifikasi sebesar $12,19 \%$. Tingginya kadar protein tepung biji nangka yang dimodifikasi disebabkan karena penambahan enzim $\alpha$-amilase yang digunakan berasal dari

Karakteristik Cookies dari Tepung Terigu dan Tepung Biji Nangka Dimodifikasi Secara Enzimatis/Siska
Cicilia $^{1 *}$, Eko Basuki $^{1 *}$, Ahmad Alamsyah
$1^{*}$, I Wayan Sweca Yasa ${ }^{1 *}$, Lingga Gita Dwikasari $^{*}$, Rafika Suari $^{2}$
Journal of Agritechnology and Food Processing
Volume 1, No. 1, 2021
Jl. K. H. Ahmad Dahlan No. 1, Pagesangan-Mataram, Indonesia 
kecambah kacang hijau dengan tanpa mengekstraknya, hal ini menyebabkan kadar protein tepung biji nangka dimodifikasi cenderung semakin naik seiring dengan konsentrasi penambahan enzim sebanyak 35\%. (Hadi et al., 2017)juga menyatakan semakin banyak tepung biji nangka yang digunakan maka kadar protein pada produk flakes akan semakin meningkat. Hasil analisis bahan baku didapatkan kadar protein tepung biji nangka 12,08\%. Kadar protein pada cookies minimum yang telah ditetapkan dalam SNI 01-2973-1992 adalah minimum 9\%. Hasil penelitian didapatkan bahwa kisaran kadar protein cookies dengan perbandingan konsentrasi tepung biji nangka dimodifikasi dan tepung terigu yaitu $6,14-9,15 \%$. Hal ini menunjukan bahwa kadar protein dengan konsentrasi $25 \%$ tepung terigu dan $75 \%$ biji nangka dimodifikasi pada produk cookies sudah memenuhi standar mutu seperti yang ditetapkan oleh Badan Standar Nasional.

\section{Kadar Lemak}

Lemak merupakan senyawa kimia yang mengandung unsur $\mathrm{C}, \mathrm{H}$ dan $\mathrm{O}$. Lemak merupakah salah satu nutrisi yang diperlukan tubuh karena kegunaannya untuk menyediakan energi sebesar $9 \mathrm{kl}$ atau gr. Lemak berfungsi melarutkan vitamin A, D, E dan $\mathrm{K}$ serta menyediakan lemak esensial bagi tubuh.Pengaruh penambahan tepung biji nangka dimodifikasi terhadap kadar lemakcookies dapat dilihat pada Gambar 4.

Gambar 4 menunjukkan bahwa semakin tinggi penambahan tepung biji nangka dimodifikasi pada pembuatan cookies maka kadar lemak cookies tersebut semakin meningkat dengan pola regresi linear dengan persamaan regresi $y=0,474 x+15,706$ dan dengan koefisien determinasi $(R 2)=0,7951$. Nilai 0,474x menentukan arah regresi linear. Nilai positif pada angka ini menunjukkan hubungan yang positif terhadap penambahan tepung biji nangka dimodifikasi. Semakin tinggi penambahan tepung biji nangka dimodifikasi maka akan terjadi peningkatan pada kadar lemak pada cookies sebesar 0,474. Nilai 15,706merupakan konstanta atau disebut intercept dimana pada titik $x=0$, kadar abu sebesar 15,706 . Nilai koefisien determinasi (KD) sebesar 0,7951 dikonversi ke \% sehingga menjadi 79,51\%, artinya yaitu peningkatan kadar lemak cookies dipengaruhi sebesar $79,51 \%$ oleh penambahan tepung tepung biji nangka dimodifikasi dan sisanya sebesar $20,49 \%$ dipengaruhi oleh faktor lain.

10 Karakteristik Cookies dari Tepung Terigu dan Tepung Biji Nangka Dimodifikasi Secara Enzimatis/Siska
Cicilia $^{1 *}$, Eko Basuki ${ }^{1 *}$, Ahmad Alamsyah ${ }^{1 *}$, I Wayan Sweca Yasa ${ }^{1 *}$, Lingga Gita Dwikasari $^{*}$, Rafika Suari $^{2}$
Journal of Agritechnology and Food Processing
Volume 1, No. 1, 2021
Jl. K. H. Ahmad Dahlan No. 1, Pagesangan-Mataram, Indonesia 


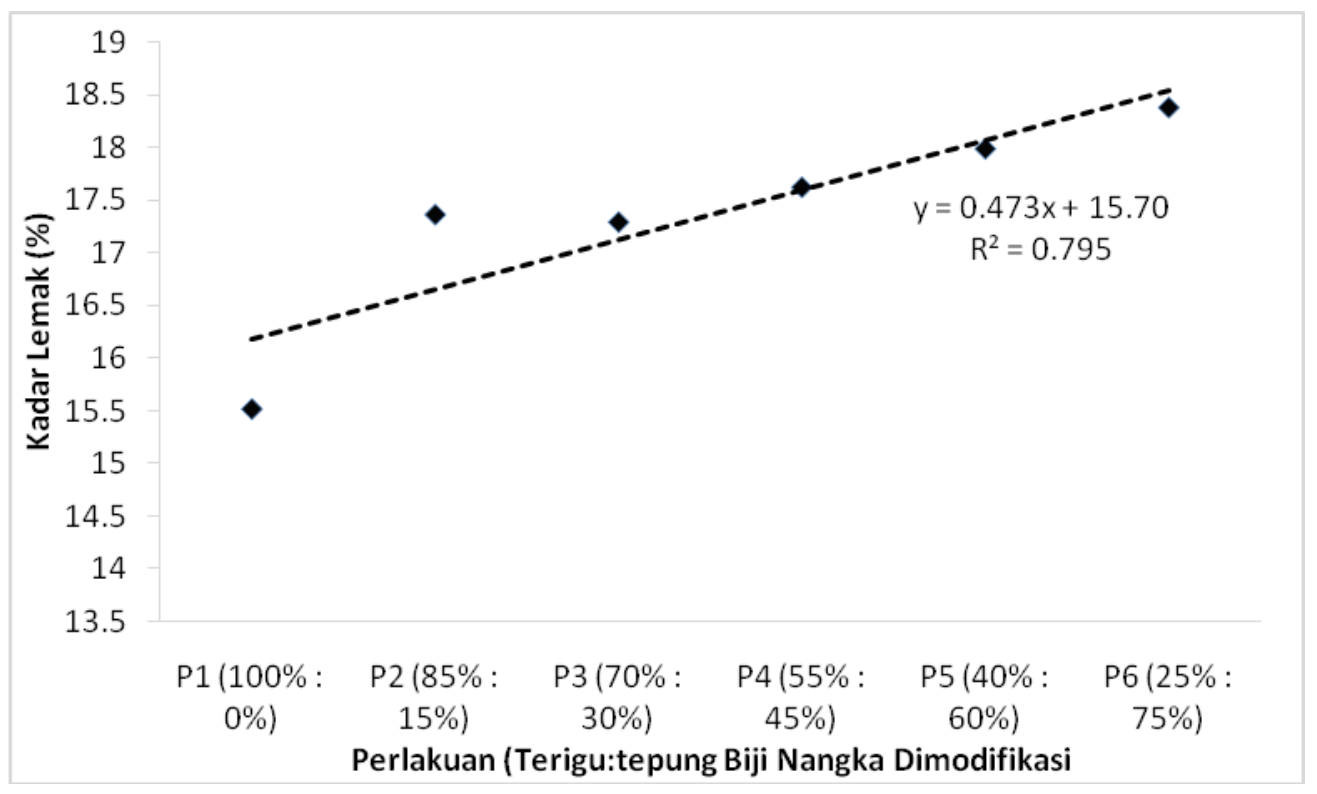

\section{Gambar 4. Grafik Pengaruh Penambahan Tepung Biji Nangka Dimodifikasi terhadap Kadar Lemak Cookies}

Peningkatan kadar lemak seiring dengan penambahan tepung biji nangka dimodifikasi karena lebih besar dari pada terigu, kadar lemak pada tepung biji nangka setelah dimodifikasi yaitu 1,34\% dan tepung terigu sebesar $1,21 \%$. Tingginya kadar lemak cookies yang dihasilkan diduga dipengaruhi oleh penambahan bahan lainnya seperti margarin, susu bubuk dan telur. Margarin yang digunakan memiliki kadar lemak sebesar $80 \%$, sehingga semakin banyak margarin yang ditambahkan maka kadar lemaknya juga semakin meningkat. Menurut penelitian (Islam et al., 2015) dengan substitusi tepung biji nangka pada pembuatan cookies, hasil yang diperoleh yaitu semakin tinggi tingkat substitusi tepung biji nangka pada pembuatan cookies menyebabkan semakin tinggi kadar lemak, kadar protein dan kadar abu, akan tetapi daya terima produk yang dihasilkan sebagian besar mengalami penurunan. Hasil penelitian didapatkan bahwa kisaran kadar lemak cookies dengan perbandingan konsentrasi tepung biji nangka termodifikasi dan tepung terigu yaitu $15,5-18,4 \%$. Hal ini menunjukan bahwa kadar lemak produk cookies belum memenuhi standar mutu seperti yang ditetapkan oleh Badan Standar Nasional.

\section{E. Organoleptik}

Sifat organoleptik merupakan salah satu sifat penting pada pangan yang perlu diperhatikan selain kandungan gizinya. Pengujian organoleptik didasarkan pada pengujian menggunakan indra atau pengindraan yang bersifat subyektif karena hasilnya sangat ditentukan oleh panelis yang melakukan pengujian. Sifat organoleptik yang sering diujikan

11 Karakteristik Cookies dari Tepung Terigu dan Tepung Biji Nangka Dimodifikasi Secara Enzimatis/Siska Cicilia $^{1 *}$, Eko Basuki ${ }^{*}$, Ahmad Alamsyah $^{1 *}$, I Wayan Sweca Yasa ${ }^{1 *}$, Lingga Gita Dwikasari $^{1 *}$, Rafika Suari $^{2}$

Journal of Agritechnology and Food Processing

Volume 1, No. 1, 2021

Jl. K. H. Ahmad Dahlan No. 1, Pagesangan-Mataram, Indonesia 
dalam pangan adalah rasa, warna, tekstur, dan aroma yang bias diuji secara hedonic dan skoring.

Rasa merupakan faktor yang penting untuk menentukan tingkat penerimaan suatu bahan pangan atau makanan. Meskipun warna dan aroma baik, jika tidak diikuti rasa yang enak maka makanan tersebut tidak akan diterima oleh konsumen(Winarno, 2004).Suatu bahan pangan yang dinilai enak dan teksturnya baik tidak akan dimakan apabila memiliki warna yang kurang sedap dipandang atau telah menyimpang dari warna yang seharusnya.Tekstur merupakan sensasi tekanan yang data diamati dengan mulut (pada waktu digigit, dikunyah dan ditelan) ataupun perabaan dengan jari. Ciri yang paling penting yang sering digunakan sebagai acuan untuk penilaian tekstur suatu makanan adalah kepadatan.Pengaruh penambahan tepung biji nangka dimodifikasi terhadap nilai skoring tekstur, warna, dan rasa cookies dapat dilihat pada Gambar 5.

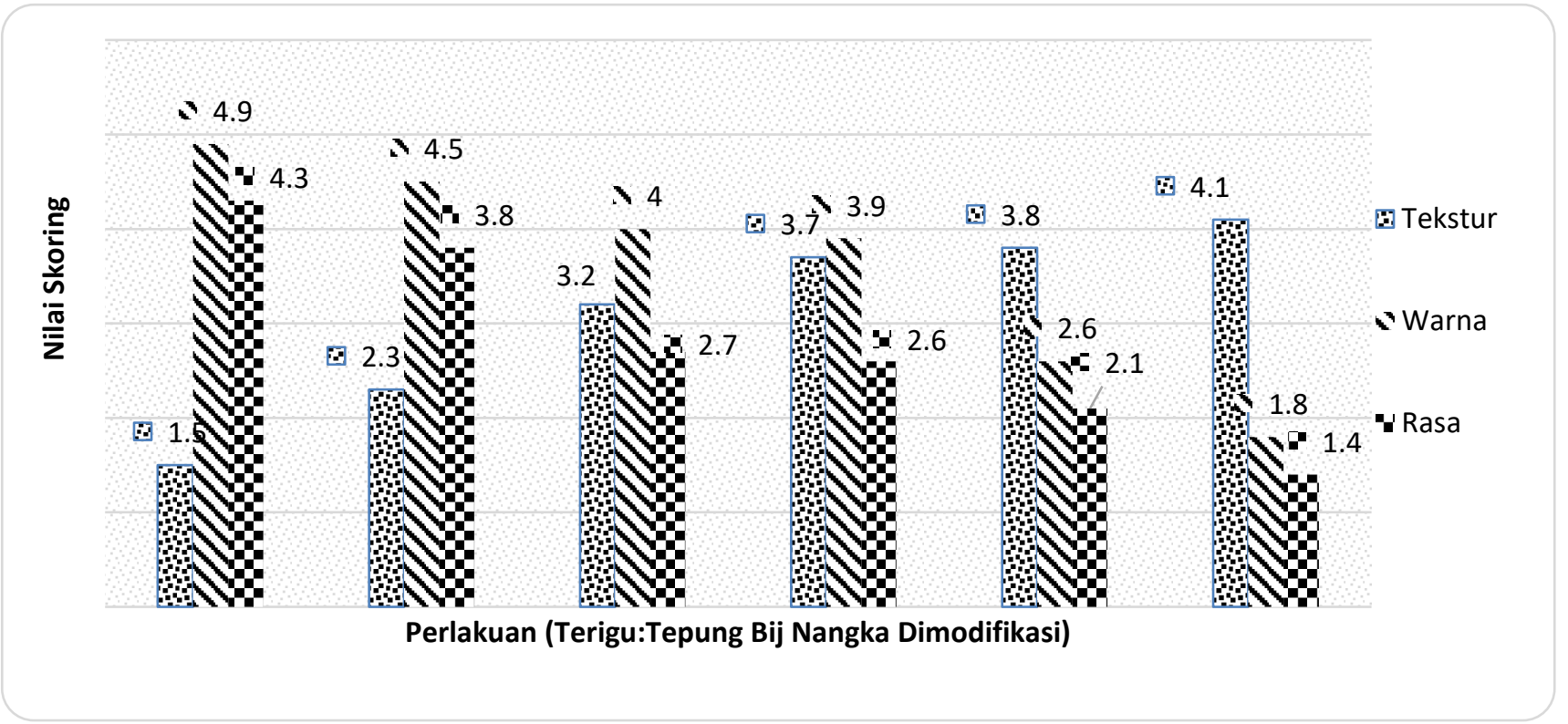

\section{Gambar 5. Grafik Pengaruh Penambahan Tepung Biji Nangka Dimodifikasi terhadap Kadar Tekstur, Warna, dan Rasa Cookies}

Gambar 5 menunjukkan bahwa rata-rata panelis memberikan nilai sensoris rasa cookies terhadap tingkat penilaian (skoring) rata-rata panelis memberikan nilai pada rentang 1,4-4,3 (tidak berasa pahit sampai berasa pahit) dengan nilai tertinggi pada P6 dengan proporsi $25 \%$ tepung terigu dan $75 \%$ tepung biji nangka dimodifikasi dikarenakan kandungan asam amino yang terkandung pada tepung biji nangka dimodifikasi sehingga membuat produk cepat sekali gosong dan memiliki rasa pahit, terendah pada perlakuan P1 dengan proporsi $100 \%$ tepung terigu tanpa penambahan tepung biji nangka dimodifikasi.

Karakteristik Cookies dari Tepung Terigu dan Tepung Biji Nangka Dimodifikasi Secara Enzimatis/Siska
Cicilia $^{1 *}$, Eko Basuki ${ }^{1 *}$, Ahmad Alamsyah ${ }^{1 *}$, I Wayan Sweca Yasa ${ }^{1 *}$, Lingga Gita Dwikasari $^{*}$, Rafika Suari $^{2}$
Journal of Agritechnology and Food Processing
Volume 1, No. 1, 2021
Jl. K. H. Ahmad Dahlan No. 1, Pagesangan-Mataram, Indonesia


Rasa yang terbentuk pada cookies tepung biji nangka dikaitkan dengan adanya komponen kimia pada bahan yang digunakan pada pembuatan cookies, yaitu asam amino, gula, dan komponen aromatik. Asam amino dan gula merupakan reaksi non enzimatis yang mengakibatkan terjadinya reaksi maillard yang berpengaruh terhadap kualitas makanan, salah satunya yaitu pada pembentukan rasa. Sedangkan adanya komponen aromatik yang terdapat pada tepung biji nangka mengindikasi adanya flavanoid yang merupakan komponen non-volatil pembentuk rasa (Theivasanthi dkk, 2011 dan Moskowitz, 2012).

Menurut (Adam, 2019), pada penelitian uji daya terima konsumen terhadap cookies yang disubstitusi tepung biji nangka, perlakuan subsitusi cookies tepung biji nangka tidak ada pengaruh pada rasa yang dihasilkan. Hal ini disebabkan karena rasa yang dihasilkan dari cookies tanpa penambahan tepung biji nangka tersebut memiliki cita rasa yang berbeda dimana rasa yang dihasilkan pada cookies tanpa tepung biji nangka tersebut hanya terasa manis. Manis yang dirasakan oleh panelis disebabkan karena adanya penambahan gula dan susu.

Penilaian skoring warna menunjukkan bahwa rata-rata panelis memberikan nilai pada rentang 1,8-4,9 (berwarna coklat sampai kuning) dengan nilai tertinggi pada P1 karena bahan baku tepung biji nangka dimodifikasi memiliki warna yang lebih gelap dibandingkan tepung terigu dan terendah pada perlakuan P6. Hal ini menunjukkan bahwa rata-rata panelis menilai cookies dengan penambahan tepung biji nangka dimodifikasi mempunyai warna yang lebih coklat dibandingkan dengan perlakuan tanpa penambahan tepung biji nangka dimodifikasi. Semakin banyak penambahan tepung biji nangka dimodifikasi yang digunakan maka warna cookies akan makin coklat. Hal ini disebabkan oleh warna bahan dasar yaitu tepung biji nangka dimodifikasi memiliki warna lebih gelap dari pada tepung terigu. Warna cokelat pada cookies juga disebabkan oleh proses pemanggangan adonan yang merupakan reasksi Maillard. Reaksi Maillard terjadi bila gula reduksi bereaksi bereaksi dengan senyawa-senyawa yang memiliki gugus $\mathrm{NH}_{2}$ (protein, asam amino, dan peptida). Reaksi ini terjadi bila bahan pangan dipanaskan. Ketika gula pereduksi bereaksi dengan sebuah gugus amina primer atau sekunder akan membentuk suatu glukosamin. Komponen ini selanjutnya membentuk komponen berwarna gelap melanoidin yang menyebabkan perubahan warna pada bahan pangan (Winarno, 2004).

Berdasarkan penilaian skoring tekstur menunjukkan bahwa rata-rata panelismemberikan nilai pada rentang 1,5-4,1 (tidak padat sampai padat) dengan nilai tertinggi pada P6 karena semakin tinggi penambahan tepung biji nangka dimodifikasi menyebabkan adonan cookies menjadi padat dan keras dan terendah pada perlakuan P1. Hal ini menunjukkan bahwa rata-rata panelis menilai cookies dengan penambahan tepung biji nangka dimodifikasi mempunyai tekstur yang lebih padat dibandingkan dengan

Karakteristik Cookies dari Tepung Terigu dan Tepung Biji Nangka Dimodifikasi Secara Enzimatis/Siska
Cicilia $^{1 *}$, Eko Basuki ${ }^{1 *}$, Ahmad Alamsyah ${ }^{1 *}$, I Wayan Sweca Yasa ${ }^{1 *}$, Lingga Gita Dwikasari $^{*}$, Rafika Suari $^{2}$
Journal of Agritechnology and Food Processing
Volume 1, No. 1, 2021
Jl. K. H. Ahmad Dahlan No. 1, Pagesangan-Mataram, Indonesia


perlakuan tanpa penambahan tepung biji nangka dimodifikasi. Nilai kepadatan cookies dapat dipengaruhi kandungan protein pada tepung biji nangka dimodifikasi yang lebih tinggi dibandingkan tepung terigu. Pada suhu tinggi protein akan mudah terdenaturasi akibat putusnya ikatan hydrogen yangn membentuk struktur heliks, kemudian protein akan berintraksi dengan air (Rauf, 2015). Air teradsorbsi ke dalam pati ketika terjadi gelatinisasi pada saat pengovenan dapat menyebabkan kadar air pada cookies menurun, sehingga mempengaruhi kepadatan cookies menjadi semakin keras. Selain itu kandungan amilosa pada tepung biji nangka lebih tinggi dibanding tepung terigu akan menyebabkan kepadatan cookies semakin meningkat.

\section{SIMPULAN}

Perlakuan penambahan tepung biji nangka dimodifikasi pada pembuatan cookies memberikan pengaruh yang berbeda nyata terhadap kadar air, abu, protein, lemak dan warna, rasa, dan tekstur secara skoring. Semakin tinggi penambahan tepung biji nangka dimodifikasimeningkatkan kadar air, protein, lemak, dan abu dan warna cookies semakin gelap, rasa semakin pahit, serta tekstur semakin padat. Perlakuan dengan perbandingan tepung terigu 55\%:45\% tepung biji nangka dimodifikasi merupakan perlakuan terbaik dengan kadar air 6,94\%; kadar abu 1,13\%; kadar protein 7,95\% dan kadar lemak 17,63\%.

\section{DAFTAR PUSTAKA}

Adam, M. and A. (2019). Uji Daya Terima Konsumen Terhadap Cookies yang Disubtitusi Biji Nangka. Psikologi Perkembangan, IV(October 2013), 1-224.

Adelina, E., \& Tiwow, V. M. A. (2020). Aplilkasi Teknologi Budidaya dan Diversifikasi Olahan Buah Nangka Unggul Kota Palu. MOSINTUVU: Jurnal Pengabdian Pada Masyarakat. https://doi.org/10.22487/monsituvu.v1i1.444

Adikhairani. (2012). Pemanfaatan Limbah Nangka ( Biji: Artocarpus Hete Rophyllus, Lmk Dan Dami Nangka ) Untuk Pembuatan Berbagai Jenis Pangan Dalam Rangka Penganekaragaman Penyediaan Pangan. Jurnal Pendidikan Teknologi Dan Kejuruan FakultasTeknik Unimed.

Andyarini, E. N. dan I. H. (2017). Analisis proksimat pada tepung biji Nangka (Artocarpus Heterophyllus Lamk.). KLOROFIL: Jurnal IImu Biologi Dan Terapan.

Daeng, R. A. (2019). Pemanfaatan Tepung Tulang Ikan Cakalang (Katsuwonus pelamis) sebagai Sumber Kalsium dan Fosfor untuk Meningkatkan Nilai Gizi Biskuit. JURNAL BIOSAINSTEK. https://doi.org/10.52046/biosainstek.v1i01.209

14 Karakteristik Cookies dari Tepung Terigu dan Tepung Biji Nangka Dimodifikasi Secara Enzimatis/Siska
Cicilia $^{1 *}$, Eko Basuki ${ }^{1 *}$, Ahmad Alamsyah ${ }^{1 *}$, I Wayan Sweca Yasa ${ }^{1 *}$, Lingga Gita Dwikasari $^{*}$, Rafika Suari $^{2}$
Journal of Agritechnology and Food Processing
Volume 1, No. 1, 2021
Jl. K. H. Ahmad Dahlan No. 1, Pagesangan-Mataram, Indonesia 
Hadi, N., Yusmarini, \& Efendi, R. (2017). Pemanfaatan Tepung Biji Nangka dan Tepung Jagung dalam Pembuatan Flakes. Universitas Riau Jom FAPERTA.

Hariyadi, H., Sulastri, Y., \& Zainuri, Z. (2020). Pengaruh Konsentrasi Kecambah Kacang Hijau Terhadap Sifat Fisik Dan Kimia Tepung Talas Kimpul. Pro Food. https://doi.org/10.29303/profood.v6i1.135

Islam, M. ., Begum, R., Khatun, M., \& Dey, K. . (2015). A Study on Nutritional and Functional Properties Analysis of Jackfruit Seed Flour and Value Addition to Biscuits. International Journal of Engineering Research \& Technology (IJERT).

Kisnawaty, S. W., \& Kurnia, P. (2017). Pengaruh Substitusi Tepung Biji Nangka Pada. 91-104.

Ma'rufah, A., Ratnani, R. D., \& Riwayati, I. (2016). Pengaruh Modifikasi Secara Enzimatis Menggunakan Enzim $\alpha$-Amilase dari Kecambah Kacang Hijau Terhadap Karakteristik Tepung Biji Nangka (Artocarpus heterophyllus Lamk. Jurnal Inovasi Teknik Kimia, 1(2), 65-70.

Santoso, M. T., Hidayati, L., \& Sudjarwati, R. (2014). Pengaruh Perlakuan Pembuatan Tepung Biji Nangka Terhadap Kualitas Cookies Lidah Kucing Tepung Biji Nangka. Jurnal Teknologi Dan Kejuruan.

Suarni, S., Harlim, T., Upe, A., \& Patong, A. R. (2010). THE ENZYMATIC EFFECT (A-AMYLASE) ON VISCOSITY AND CARBOHYDRATE COMPOSITION OF MAIZE FLOUR MODIFIED. Indonesian Journal of Chemistry. https://doi.org/10.22146/ijc.21702

15 Karakteristik Cookies dari Tepung Terigu dan Tepung Biji Nangka Dimodifikasi Secara Enzimatis/Siska Cicilia $^{1^{*}}$, Eko Basuki $^{{ }^{*}}$, Ahmad Alamsyah $^{1 *}$, I Wayan Sweca Yasa ${ }^{1 *}$, Lingga Gita Dwikasari ${ }^{*}$, Rafika Suari $^{2}$ Journal of Agritechnology and Food Processing Volume 1, No. 1, 2021

Jl. K. H. Ahmad Dahlan No. 1, Pagesangan-Mataram, Indonesia 